\title{
Investments in Braskem green polymers: extraordinary profits or decarbonization of the environment?
}

\author{
Eliana L. Hellvig and Thais H.S.Flores-Sahagun \\ Federal University of Paraná, Mechanical Engineering Department, Curitiba, \\ Paraná, Brazil
}

\begin{abstract}
Braskem is the only company in the world that produces green polyethylenes (HDPE high density polyethylene and LLDPE - linear low density polyethylene) derived from the dehydration of sugarcane ethanol. Although the performance of green and fossil nominally same polyethylenes are equivalent, commercial clients may use blends of up to $51 \%$ of green polyethylenes and $49 \%$ of fossil polyethylenes and still have the right to use the I'm green ${ }^{\mathrm{TM}}$ label which appeals to environmental conscious consumers and places these companies in a noticeable position. The Annual Income Statement - AISs from 2010, when Braskem started production of green PE, until 2018, show there was growth of revenues. Despite of the production of polyethylenes have continued stable and the number of green polyethylenes patents have decreased since 2014, the profits with the BRKM5 stocks increased. There is no transparency of how carbon credits were gained and in the AIS. Investments in securities in the Brazilian financial market (BRKM5 and carbon credits) are much more attractive than the investment in new patents, because they generate greater gains $(268 \%$ increase in the average share price of BRKM5 from 2012 to 2018) and do not require large investments in R\&D.
\end{abstract}

Keyword: carbon credits; green polyethylenes; Braskem; I'm green; BRKM5; patents 


\section{Introduction}

Green plastics have received special attention from industry and governments around the world as they are produced from raw materials of vegetable origin and can contribute to the reduction of Greenhouse Gas (GHG) emissions and the environmental pollution generated by plastic, which cause severe damage to ecosystems and the quality of life of the world's population. In this context, this paper presents a case study about Braskem, the only company that produces green polyethylenes obtained from sugarcane in the world [1] (WATERS, 2017), aiming to discuss issues related to the gains that companies have when investing in green polymers and their potential impact in decarbonizing the environment.

It is important to address transparency and compliance in the world trade business because confidence attracts new investors, stakeholders and customers [2-3] BORSATTO et al. 2020; PEREIRA et al., 2020). Innovative green technology is an important tool to obtain international competitive advantages in the global markets and some authors consider quality of products as the best guarantee long-term competitiveness of firms and countries. [4] (APAK \& ATAY, 2015). However, transparency (in carbon credits and AIS - Annual Income Statement of green stocks BRKM5) should be of utmost importance to consolidate the company in the global market because it shows consumers, commercial clients and stakeholders that investments in green technologies contribute effectively to generate environmental benefits besides profits. Braskem, a huge Brazilian company, places Brazil in a noticeable position regarding the production of green polyethylenes and other products. It is essential that Brazil is seen as a country where good corporate governance practices are adopted so that investors can bring new opportunities for the country. In fact, However, Braskem also trades in other stock exchange markets throughout the world and should be completely transparent. Whenever lack of transparency occurs, it should be addressed and rectified. However, we were informed that only shareholders have access to this information according to the regulations currently in force in the financial market, as established by B3 and the Securities and Exchange Commission of Brazil (CVM).

However, we were informed that only shareholders may have access to this information, according to the rules currently in force in the financial market, as established by B3 and the Securities and Exchange Commission of Brazil (CVM). However, B3 is agreed to the international financial market rules, such as the Sarbanes- 
Oxley Act (SOX), which determines transparency of all business activities. Therefore, B3 must submit the reports to the public. Thus, non-compliance with the rule was observed.

In order to better understand these issues, Braskem's innovation and technological development related to green polyethylenes (PEs) and polypropylene (PP), the role of carbon credits as financial instruments for the decarbonization of the environment will initially be addressed. In the Results and Discussion section, the evolution of patents for green PEs and PP filed at the United States Patent and Trademark Office - USPTO from 1999 to 2017 will be evaluated from the point of view of market concentration, among other issues such as the companies that have invested the most in these technologies and the types of products that can be manufactured. The study will also discuss the advantages of the use of Braskem green polymers by corporate customers and their gains in terms of marketing and image promotion; the gains of BRKM5 from 2007 to 2018 in the São Paulo stock exchange (B3); and the gains from carbon credits.

Green ethene, monomer used in the production of green polymers, is obtained from the dehydration of ethanol [1;5] (WATERS, 2017; OKSMAN, 2014). The United States of America (USA) and Brazil are the main producers of ethanol in the world, and ethanol produced in the USA is obtained from corn and, in Brazil, from sugarcane [6] (AMAN, 2013). Although ethanol produced from corn and sugarcane - as well as from other raw materials of vegetable origin, such as corn, cassava and beet - are equal products, considering the total production cycle, only ethanol from sugarcane removes $\mathrm{CO}_{2}$ from the environment [6-8] (DIAS, 2015; AMAN, 2013; GARCIA, 2020). Thus, the production of green ethene from the dehydration of sugarcane ethanol is valuable because, besides opening a wide range of possibilities for the production of green and environmentally friendly polymers, it generates carbon credits. It is important to note, however, that although green ethene comes from a renewable source, green polyethylenes and green polypropylene are not biodegradable polymers and may be as pollutant as the fossil same polymers.

There is a controversy in the literature regarding the values of decarbonization of the environment through the production of sugarcane ethanol. According to [9] (COUTINHO,2003), each ton of green ethene removes 3.5 ton of $\mathrm{CO}_{2}$ from the environment, while for [10] (BASTOS, 2007) the value is 2.5 tons. The life-cycle greenhouse gas emissions and energy balances of sugarcane ethanol production in Mexico and in Brazil was discussed elsewhere [8] (GARCIA et.al,2019). However, in 
the Braskem site there is a video where the information is that each ton of green ethene removes 4.75 ton of $\mathrm{CO}_{2}$ from the environment and this value will be used in this case study for the calculation of carbon credits owed by the green ethene production [11] (BRASKEM, 2020). Case studies of specific countries or companies are interesting to evaluate clean technologies worldwide [11-14] (SAJID, 2020; QU, 2020; HELLVIG, 2019; BRASKEM, 2020).

This study includes a survey of the technologies protected by patents of invention used in products and processes for obtaining green PEs (HDPE - high density polyethylene and PELBD - linear low density polyethylene) and green PP filed in the USPTO patent database in a period of 18 years. In this work, through the related patentometry [15] (OLIVEIRA, 2019) it was evaluated how the technologies for the production and use of polyethylenes (PEs) and green polypropylenes evolved from 1999 to 2017. The USPTO was chosen because it has a wider scope, when compared to the European patent office. Another relevant factor is that, by providing greater access to information, it makes it possible to answer a greater number of questions related to the development of research in the sector, as well as discussing issues related to the gains that companies have when investing in green polymers.

It was concluded that the USA has a high concentration of companies holding patents on green PEs and PP, although they do not produce these polymers. This could mean that the major goal of research and development (R\&D) investment is to own technology and obtain gains through royalties from technology transfer. Braskem's

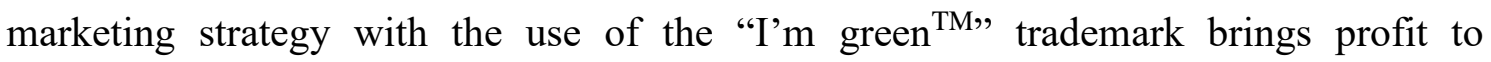
corporate customers who use this label to promote a positive image of their companies. Braskem has had capital gains from carbon credits since 2010, when the production of green ethene from sugarcane began. With the financial speculation of BRKM5, Braskem's green shares, on B3, the average share price increased 268\% between 2012 and 2018. When analyzing Braskem's Annual Income Statements (AISs) from 2007 to 2010, the year in which the production of green PE was commercially launched, it was observed that the company had its earnings increased. Braskem might have much larger capital gains with carbon credits than its AIS, there is no transparency when it comes to the trading of BRKM5 assets or carbon credits. The Sarbanes-Oxley - Sox Law [16] (ASSAF, 2012), signed in the USA in 2002 and applied in Brazil since 2007, at the time of the restructuring of the São Paulo stock exchange [17] (BOVESPA, 2018), determines that all companies that participate in the financial market adopt good 
corporate governance practices (compliance). The Central Bank of Brazil (BACEN) has the role to supervise the National Financial System in Brazil but although transparency is said to be mandatory in order to corporate customers trade in the B3, only investors may have access to this information [18] (BACEN, 2019).

The main objective of the paper was to show how a Brazilian company, Braskem, manages to make extraordinary profits using the production of green polymers, environmental appeal and a marketing strategy that uses the "Im Green TM" label on non-biodegradable plastics (green HDPE and LLDPE) produced from ethene derived from the dehydration of sugarcane ethanol. Innovative green technology may attract new stakeholders, commercial clients and consumers. However, transparency in carbon credits report and AIS of greens stocks BRKM5 are essential in order to guarantee long-term international competitiveness of Braskem.

\section{Innovation and technological development of Braskem green PEs}

Green PE is produced at the Triunfo petrochemical complex, in the southern state of Rio Grande do Sul, which has a production capacity of 200,000 tons per year, and US\$ 290 million in investments in the plant. The transformation of green ethene into green polyethylene "I'm green ${ }^{\mathrm{TM}}$ " is carried out in the same plant, but in different reactors. The ethanol used in the production of green PE is largely provided through contracts with major domestic producers, whose relationship with Braskem is governed by the Code of Conduct for Ethanol Suppliers (CCFE), so that good practices are implemented [19] (MENEGUETTI, 1999).

The "I'm green"TM" PEs are considered drop-in biopolymers because they replace conventional PEs without the need for investments in new plastic processing machines [20-23] (MOHANTY, 2002; DE PAOLI, 2008; SCOTT, 2000; ALTINBALIK, 2018). Green polyethylenes are not biodegradable but they are biopolymers because the main raw material is green ethene. Polyethylenes, green and fossil, are recyclable and more resistant, specially to moisture, than the biodegradable polymers. Packaging is the main application of polyethylenes. Although many authors have developed biodegradable materials such as hemicellulose/chitosan films [24] (XU, 2019), soy protein films [2526] (GONZÁLEZ, 2019; MARTELLI-ROSA, 2018), Cassia gum films [27] (CAO, 2020) for packaging, polyethylenes are the most common polymers used. Green composites [28-29] (DICKER, 2014; MOSTAFA, 2019), nanocellulose composites [30] 
(LIN, 2019) and PLA/cellulose nanocrystal composites [31] ( HEGYESI, 2019) are green materials [5] (OKSMAN, 2014) such as plasticized poly(3-hydroxybutyrate), cellulose/poly(butylene succinate) composites [32-33] (SEOANE, 2018; PLATNIEKS, 2020) and starch based polymers [30] (LIN, 2019) but do not replace polyethylenes due to its durability, resistance to water and lower cost.

In 2010, Vinçotte, the Belgian inspection and certification organization, certified the renewable content of Braskem's green polyethylenes. Renewable content is one of the most important attributes of green PEs and PP and it expresses the percentage of renewable carbon relative to the total mass of the material or product [34] (HEINZEN, MATTOS, CAMPOS \& PALADINI, 1999). Braskem's HDPE presents a minimum renewable content of $96 \%$ while LLDPE shows a minimum renewable content of $89 \%$. The renewable content of green LLDPE could be increased producing butene and hexene of vegetable origin. However, it is likely that the production cost of the green monomers butene, propene and hexene from sugarcane ethanol would not be economically viable [35] (NEVES, TROMBINI \& CONSOLI, 2010).

Braskem's green PEs are the only ones produced on an industrial scale in the world. Conventional PEs (HDPE and LLDPE) can be replaced by equivalent green polymers, since they are nominally equal products. However, subtle differences that do not alter their performance may exist, since ethene from ethanol dehydration is purer than that from oil fractionation [14; 36-37] (REIS, 2009; RODRIGUES, 2011; HELLVIG, 2019). In our study, we also analyzed two pairs of fossil and green polyethylenes. Braskem data sheets of nominally same HDPE fossil and green (HC7260 and SHC7260) and of same LLDPE fossil and green (LL318 and SLL318) show that all properties listed (mechanical, density and some thermal properties) are the same. We have compared the two pair of polymers regarding composition and chemical structure and we found subtle differences between the pairs which do not affect their macroscopic performance. Green HDPE may be considered a natural composite containing approximately $10 \mathrm{wt} \%$ of inorganic filler, since thermoanalysis (TGA) showed the presence of a residue of inorganic compounds while fossil HDPE burnt completely in air. Nuclear magnetic resonance (NMR) of the two LLDPE samples showed that the ethene/butene incorporation in the polymer was different and, as also suggested by $\mathrm{x}$ ray analysis, the green copolymer was more crystalline (38 HELLVIG \& FLORESSAHAGUN, 2019). Therefore, there would be no technical reason to mix the cheaper fossil polymer with the green one unless the purpose is to obtain a cheaper material. 
However, Braskem allows its clients to mix fossil PE with green PE alleging technical reasons and if the mixture has at least $51 \%$ of the green polymer, it will be granted the "I'm green ${ }^{\mathrm{TM}}$ " seal, which results in gains in terms of marketing and the promotion of the company's image to consumers. Thus, even with the mixing of green and fossil content - which results in a $49 \%$ greater volume of material at a lower price since the green polymers are more expensive, the product can receive the "I'm green "TM" seal and enjoy the competitive advantages associated to it.

Although Braskem requires the disclosure of any product that contains green HDPE or LLDPE in its composition in a transparent manner, mentioning the percentage of polymer from renewable source, if consumers see the "I'm green ${ }^{\mathrm{TM}}$ " seal in a packaging, they will probably think the material is fully green. [11] (BRASKEM 2020).

The development of new technologies in the production of polymers obtained from renewable sources is a key to sustainability, even though only about $4 \%$ of the oil produced in the world feeds the polymer industry [39] (RAMIRES, 2006). Thus, the development and use of alternative energy sources (clean technologies) such as wind, solar, tidal, hydro and nuclear, rather than the use of oil, would lead to a drastic reduction of GHG emissions [40] (NARAJAN, 2004) and [41] (GIANNETTI, 2006). However, environmental pollution caused by plastics, low density materials that are often discarded in the form of packaging in inappropriate places, contaminates oceans, rivers and cities in a very destructive manner, severely affecting the flora of the planet [10] (BASTOS, 2008). In 2015, 407 million tons of plastic were produced worldwide and $35.9 \%$ of this total was used in packaging. Of these 407 million, 302 million tons formed plastic waste, with only $20 \%$ of the total being recycled, $25 \%$ incinerated, and 55\% discarded [42] (GEYER, BLASS, 2017). Therefore, the development of more resistant biodegradable polymers is crucial and so is the management of the recycling process of plastics, so that they can be reused, increasing their life-span and promoting the final disposal in selected locations [43] (FALCONE, 2007). The development of clean technologies such as green polymers by Braskem demonstrates concern for the environment, its decarbonization and conservation, although green polyethylenes are not biodegradable. Also, it shows interest in the profit that can be obtained in the commercialization and use of these technologies.

\section{Carbon credits as an economic instrument to decarbonize the environment}


The Kyoto Protocol is the regulatory framework for the clean development mechanism. The international instrument was signed on December 11, 1997 in Japan, ratified on March 15, 1998 and officially entered into force on February 16, 2005. The Protocol represented a milestone in international efforts to address climate change, establishing a legal commitment to reduce GHG emissions. This regulatory framework is notable for allowing the pricing of GHGs and the transaction of reduction certificates between the signatory parties, which represents an incentive for investment in alternative, lower emissions technologies [44] (LANCELLOTTI, 2010).

The Kyoto Protocol, the international agreement which established that developed countries should reduce their GHG emissions, has encouraged industries to seek alternatives to reduce emissions, to develop new technologies that could generate carbon credits, or to buy carbon credits from less developed countries. The premise underlying the agreement is that green chemistry and the use of clean technologies contribute to sustainable development and minimize the environmental impact caused by population growth and its material and energy needs.

Carbon assets are priced through the stock exchange. Pricing carbon means determining the price of the GHG emission certificates for air polluters: industries, agro-industries, oil refineries and others with carbon-intensive activities. Industries release gases into the atmosphere, generating costs that are shared among all citizens through overburdened health services, water and food shortages, and increased damage from floods or hurricanes - the so-called negative externalities from GHG emissions. The logic behind carbon credits is the following: if the polluters paid for the volume of GHG they emitted, social costs would be intertwined with private costs. In other words, the products of these industries would become more expensive, the larger their carbon footprint became. On the other hand, cleaner products would be cheaper. This is the socalled process of decarbonization of the economy. However, instead of real awareness raising towards cleaner environment and sustainability, the creation of carbon credit "derivatives" can be seen as a way of maneuvering by the "polluting giants". In practice, there are no requirements for the development of new technologies or materials for cleaner products and processes, and where decarbonization exists, it is but a small part of the whole. One might argue that, as production increases, the industry is polluting more and more, and decarbonizing less and less. Braskem produces each year 16 million tons of fossil polyethylenes and only 200.000 ton of green polyethylenes (11BRASKEM, 2020). 
The São Paulo Stock Exchange (B3) is responsible for developing and deploying systems of trading and post-trading services (clearing and settlement) of shares; shares, financial and commodities derivatives; fixed-income securities; federal public securities; spot currencies and agricultural commodities, among others. The main role of the stock exchange is to foster the national stock market in a transparent manner, following the international rules for good financial market governance practices (compliance).

Carbon credits can be defined as certificates that companies or countries buy to obtain permission to emit GHGs, where one carbon credit corresponds to one ton of carbon. GHGs are converted into units of carbon dioxide equivalent $\left(\mathrm{CO}_{2} \mathrm{e}\right)$ that can be reduced, avoided or sequestered to compensate for emissions occurring in other places and activities. $\mathrm{CO}_{2} \mathrm{e}$ is the result of multiplying tons of the emitted GHGs by its global warming potential. The global warming potential of carbon dioxide was set as 1 ; whereas methane has global warming potential of 21 , i.e., one ton of sequestered methane corresponds to 21 carbon credits; nitrous oxide has global warming potential of 310; and sulphur hexafluoride, 23.900 (17BOVESPA, 2018).

The Rio de Janeiro Stock Exchange (BVRIO) is a civil association formed by three categories: businesses, NGOs and academia, as well as citizens involved in the promotion of sustainable economic development. BVRIO offers a carbon market simulation platform, for buying and selling carbon credits. BVRIO works with companies that have adhered to the clean development mechanisms agreed in the Kyoto Protocol, thus it is considered a green market.

The rules and parameters of the simulation were built in 2013, along with participating companies, based on the emissions trading systems in operation, such as the California Stock Exchange and the European Union. From 2014 to 2017, the operational cyclical frameworks were carried out in Brazil through BVRIO's simulation platform, along with the Center for Sustainability Studies of Fundação Getúlio Vargas

The companies participating in the initiative must reconcile their emissions from the current cycle with emissions certificates that entitle them to emit one ton of CO2e. All transactions occur on the trading platform of the BVRIO Institute (Bolsa de Valores Ambientais) and are carried out in a fictional currency, EPCents (Ec\$), with parity to the Brazilian real $(\mathrm{Ec} \$ 1.00=\mathrm{R} \$ 1.00)$.

\section{Materials and methods}


The development of patents allows companies to own new technologies. The patent holder has the right to prevent third parties from producing, using, selling or importing a product subject to his or her patent and process, or processes and products obtained directly from such patent, without his or her consent. Patents reveal the technical content of the protected matter and the search in patent offices is a very useful tool when solving a specific technical problem, because it avoids duplication of R\&D activities. A patentometric analysis was used as a tool and the keywords used in the patent search were GPE (green polyethylene), GPP (green polypropylene, PE verde, PP (polypropylene), LDPE (low density polyethylene), LLDPE (linear low density polyethylene) and HDPE (high density polyethylene). [15;45] (JESUS, 2019, OLIVEIRA, 2019). São Paulo Stock Exchange (B3) site and links were used to obtain financial data from Braskem (Annual Income Statement - AIS, information about BRKM5, BRKM3 and BRKM6).

This study used the USPTO patent database for data collection, which occurred during a period of 12 months, from January 2017 to January 2018. After collection, the data were organized according to the following criteria: Country of origin of the patent x Quantity, Application x Quantity, and Type of green polymer x Quantity.

Finally, the data were organized for evaluation and quantitative analysis.

\section{Results and discussion}

\subsection{Evolution of green polymer patents in the USPTO from 1999 to 2017}

Patentometry allows technological activities to be known, technical changes over time to be analyzed and resources invested in $R \& D$ activities to be evaluated [45] (JESUS, 2019). The search in the USPTO database was made using keywords cited in the methodology and resulted in 8.226 related patents of which 1.216 came with their number, and title. However, it was necessary to read all the specifications found in order to separate the patents relating to fossil raw material from non-fossil, i.e., those specifications that actually referred to green plastics. Only 123 documents out of 1216 were selected because they were patents related to green ethene. The country with the highest number of patents is the USA, with 93 patents, followed by Brazil, with 12 patents, and Japan, with 9 patents. Regarding application, 69 patents are for products and 54 for processes. Also, regarding type of green plastic, 58 patents are for green PEs, 29 for green PP and 36 for both. 
Even though the USA appears as the country with the highest number of green patents, it does not produce green PEs or PP, nor does it produce the raw material, ethanol from sugarcane. As already discussed, the ethene obtained from the dehydration of corn ethanol does not generate carbon credits, despite being the same product as the ethene obtained from the dehydration of ethanol from sugarcane, considering the entire production cycle. It is interesting to note that Japan, England and Germany have invested in technologies for the production of green PEs, and the raw material used in the production of ethanol is often obtained from beet, sorghum and cellulose. In these cases, the interest in the detention of these technologies surpasses the possibility of producing polymers that generate carbon credits, since these raw materials do not remove more $\mathrm{CO}_{2}$ than they produce.

Braskem provides green ethene for the development of 30 of the 93 USA patents. Today, Braskem is the largest shareholder of Dow, which appears in 18 USA patents, supplying the green ethene produced by Braskem. Metabolix and the University of Southampton appear using cellulose and beet, respectively, as raw material for the production of ethanol. Graph 1 shows the companies that were found in the patent specifications.

Graph 1: companies that appear in the patent specifications surveyed

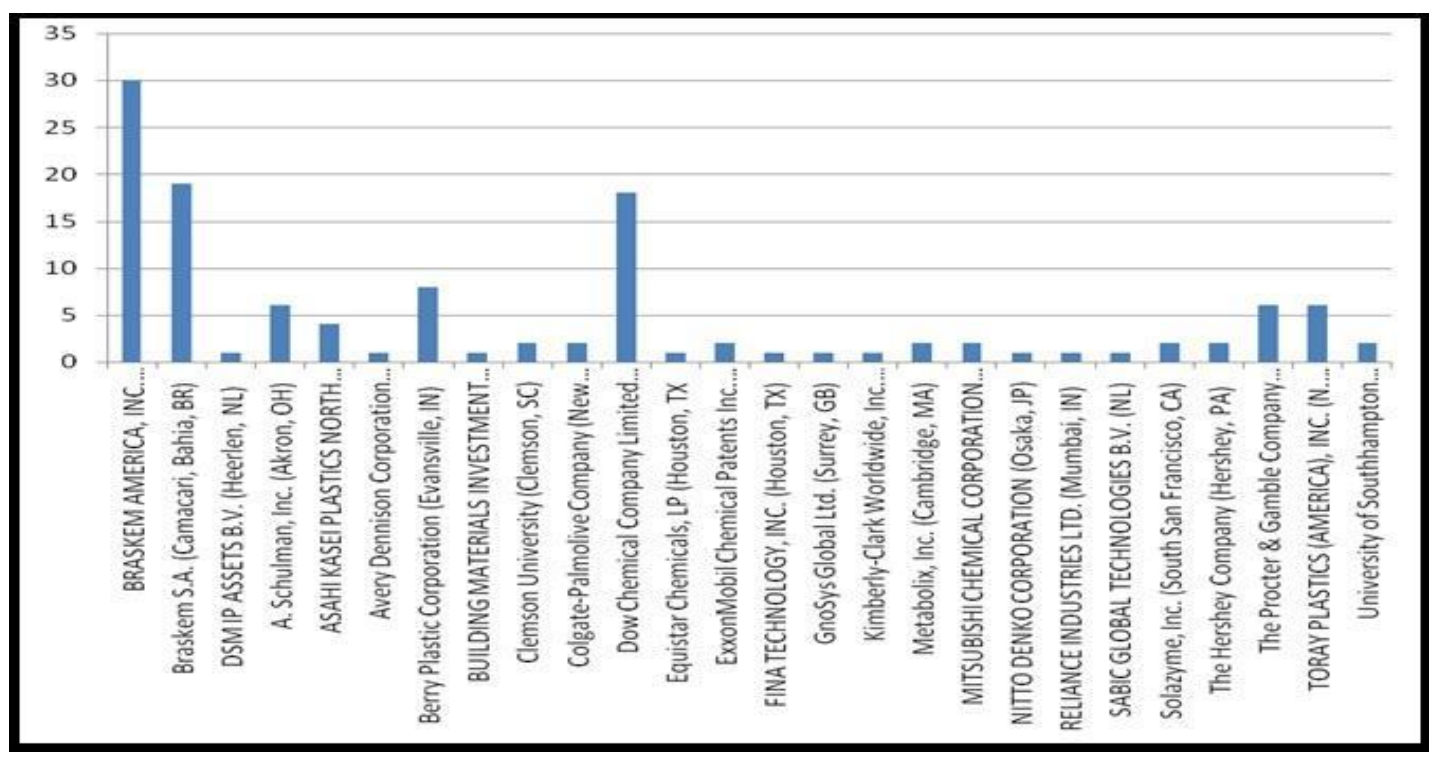

Source: Prepared by the author (2018)

Of the 123 patents granted, 54 are for processes and 69 are for products. From the 123 patents selected at the USPTO, it is possible to state that 19 were for films, 12 for packaging, and 12 for bottles, that is, the pharmaceutical, food and cosmetic industries 
are the ones that invest the most in this market. The automotive and medical products sectors appear with 3 documents each.

Graph 2 shows the number of patents year by year, from 1999 to 2017.

Graph 2 - Number of patents x Year

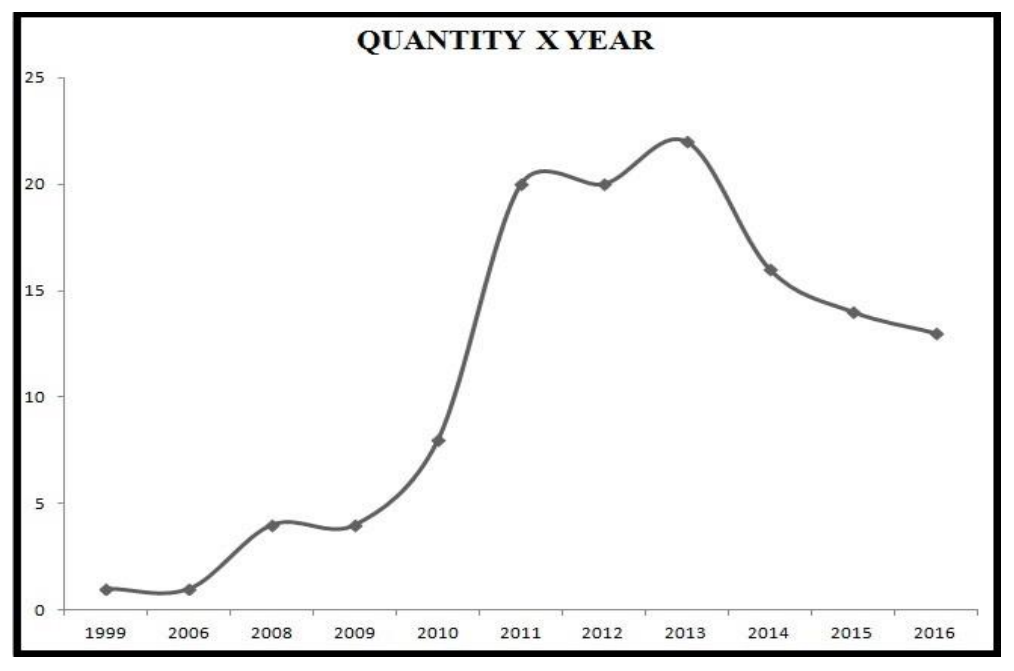

Source: Prepared by the author (2018)

It can be observed that the period with the highest number of patents takes place between 2010 and 2013, and this period coincides with initiatives generated by the Kyoto Protocol for the reduction of GHG emissions from 2008 to 2012. Another piece of information that reinforces this data is that Braskem, the world leader in the production of green PE, began its production of green PE in Rio Grande do Sul in 2010.

\subsection{Braskem and its gains in the stock exchange with BRKM5 and with carbon credits}

Braskem has three assets that are traded on the São Paulo Stock Exchange: BRKM3, BRKM5 and BRKM6. Out of these three assets, only BRKM5 is considered operative in the low carbon economy, being ranked in the Carbon Efficient Index (ICO2) of the São Paulo Stock Exchange (B3). Since B3 had access to the Braskem emissions reports to rank the company in the ICO2, this information should have been made available for the public but was not. It should be highlighted that green PEs are the only assets in the BRKM5 portfolio, because green Ethylene Vinyl Acetate (EVA) and green PP are not yet produced on an industrial scale. The stock exchange is a speculative market, so when the production of green PP was announced in 2011 and the production of green EVA was announced in 2016, there was much speculation on the financial market for the purchase of the BRKM5 stock. PE is a commodity, that is, a 
highly consumed material around the world, particularly in the plastic and packaging industry. Braskem's production capacity for green PEs is approximately $1.23 \%$ of the total PE production of Braskem.

In 2010, five patents on green PEs and PP were granted. In 2010, Braskem announced the production of green PE on an industrial scale at the Triunfo plant. In 2011, there was an increase in patents, totaling 9. In the following years, 2012 and 2013, the number of patents more than doubled, to 20 and 23 documents, respectively. As of 2013, the number of patents granted has fallen (20 documents in 2014, 14 in 2015 and 13 in 2016). In 2017, only one patent document was filed. The question is which factors contributed to such decline.

Graph 3 shows the average price of the BRKM5 shares per year since it went public, in 2007, to this date.

Graph 3 - Stock Average Price of BRKM5 X YEAR

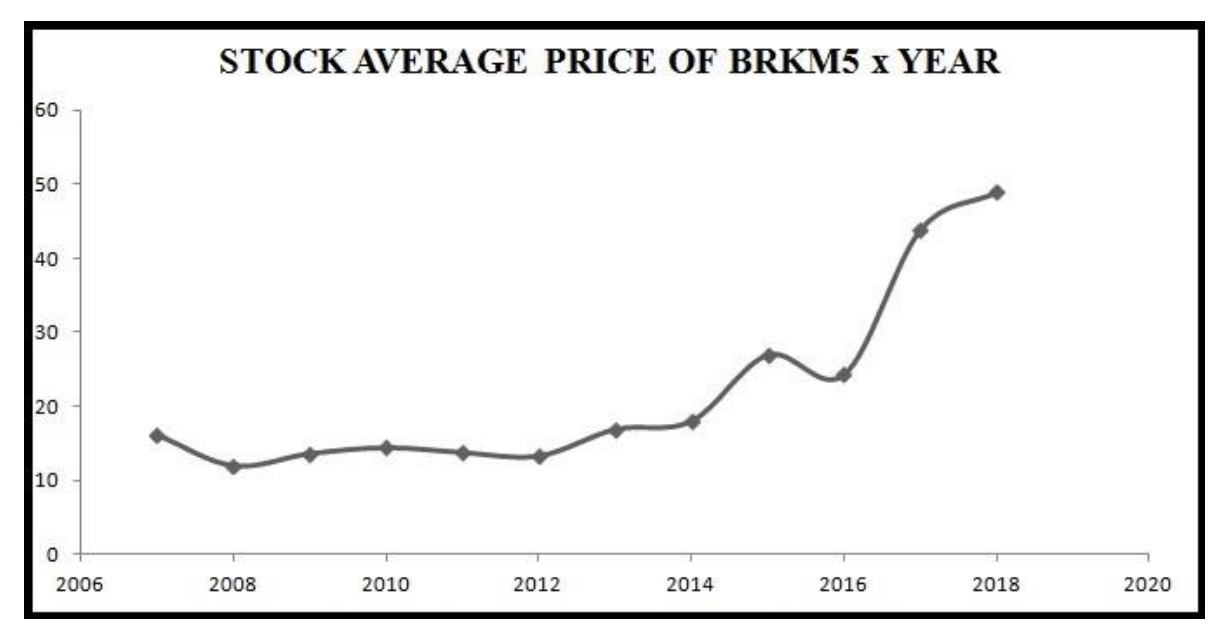

Source: Prepared by the author (2019).

Since BRKM5 is a commodity traded over the counter at B3 (Open Market) and this commodity is also traded on the New York Stock Exchange, it is a highly speculative asset, that is, any positive information regarding the company's assets promotes an elevation of its average prices. Since Green PEs account for the largest share of BRKM5 assets, Braskem is responsible for the pricing of green PEs on the stock markets in which it is listed around the globe.

It can be observed in Graph 3 that after Braskem went public on B3, with the BRKM5 asset, the Company's stock gains only increased. It should be highlighted that, although Braskem has never produced green PP on an industrial scale, the announcement that it would do so in 2011 and again in 2016, helped to raise the average prices of the BRKM5 assets, due to the speculative nature of the financial market. 
Graph 3 shows that in 2012 the average share price was $\mathrm{R} \$ 13.27$ and, in 2018 , the average price reached $R \$ 48.93$ per share, that is, a $R \$ 35.66$ growth in the average share price of BRKM5 in 6 years, representing an increase of $268 \%$.

Table 1 shows the evolution of the average prices of BRKM5 assets from 2007 to 2018 and relevant facts that could have pushed the prices up in this period.

Table 01 - Average share price X Year x relevant event in the period:

\begin{tabular}{|c|c|c|}
\hline YEAR & Arerage price of shares $\mathrm{RS}$ & RELEVANT FACTOR \\
\hline 2007 & 16,12 & Initiated Green PE production, estimated price for BRKM5 and capital opening in B3 \\
\hline 2008 & 11,95 & Announcenment of green PP production \\
\hline 2009 & 13,6 & Partnership with Novoenzymes for green PP production obtained from sugarcane \\
\hline 2010 & 14,39 & Initiated green $\mathrm{PE}$ sales and initiated I'm green ${ }^{\mathrm{TM}}$ certification \\
\hline 2011 & 13,74 & Renewable content certified by Vinçotte \\
\hline 2012 & 13,27 & Company year award (ABERLE); inauguration of new butadiene plant in Trunfo Petrochemical complex \\
\hline 2013 & 16,88 & Braskem has integrated with the first Dow Jones sustienability index \\
\hline 2014 & 18,01 & Building of the new UTEC factory in the USA \\
\hline 2015 & 26,94 & Green plastic completes 5 years in the market and conquered world market \\
\hline 2016 & 24,31 & New green $\mathrm{PP}$ production announcement and announcement of production of new resin I'm green ${ }^{\mathrm{TM}}$ EVANCE \\
\hline 2017 & 43,91 & Inauguration of new unit of ultra high molecular weight $\mathrm{PE}$, Entrance in the Carbon Disclosure Program in EUA \\
\hline 2018 & 48,93 & Initiated Boston operation and announced the industrial production of I'm green ${ }^{\mathrm{TM}}$ EVANCE resin \\
\hline
\end{tabular}

Source: Prepared by the author (2019).

In 2007, Braskem announced that it was going public on B3 and that it would produce green PE. At the company's initial public offering, the asset price reached $\mathrm{R} \$ 16.12$ per share. In 2008, the company announced that it would produce green PP, which did not occur, and the market responded with lower average asset prices. In 2009, the financial market responded well to the announcement of a partnership with Novoenzyme for the production of green PP from sugarcane. The information caused a slight rise in asset prices, giving the asset a speculative character. In 2010, the company started selling green PE and began certifying the products with the label "I'm green TM" The market's response was not exceptional, but asset prices remained high. In 2011, the information that a renowned company like Vinçotte would certify the renewable content of Brakem's products was not enough to maintain the average asset prices stable on B3 and prices fell. The drop continued until 2013. In 2013, Braskem entered the USA financial market and was first listed on the Dow Jones Sustainability Index. With this 
new fact, average prices rose again, from $\mathrm{R} \$ 13.88$ to $\mathrm{R} \$ 16.88$. In 2014, Braskem announced the construction of a new UTEC plant in the USA. UTEC is Braskem's registered trademark for Ultra-High Molecular Weight Polyethylene (UHMWPE) technology, a fossil polymer. This helped to keep the company's average asset prices high on B3. In 2015, when green plastic completed five years on the market and the company's image was consolidated worldwide, average asset prices increased significantly from $\mathrm{R} \$ 18.01$ to $\mathrm{R} \$ 26.94$, generating extraordinary profits for the company. In 2016, despite having announced that it would produce green PP and that it had started production of the "I'm green TM" Evance resin (green EVA), the company's assets depreciated somewhat in the financial market.

The great price boom for Braskem's assets took place in 2017, shortly after the company inaugurated the UTEC plant in the USA and also joined the Carbon Disclosure Project (CDP). The average asset price was $\mathrm{R} \$ 24.31$ and rose to $\mathrm{R} \$ 43.91$. The high continued into 2018, as the assets closed the trading session at the price of $\mathrm{R} \$$ 48.93.

Table 2 shows the gross results of the Annual Income Statement (AIS) of the company's stock earnings over the period 2007 to 2018. The values in dollars refer to the December quotation of each year.

Table 2: Gross AIS Result X Year

\begin{tabular}{|c|c|c|c|}
\hline YEAR & DRE-REVENUE - EXPENSES - BRASKEM S.A RS MILLION & NOMINAL RATE EXCHANGE USS & CONVERSION: REAL-DOLLAR \\
\hline 2007 & 1.696 .289 & 1,79 & $947.647,49$ \\
\hline 2008 & $1.842,84$ & 2,39 & $771.061,09$ \\
\hline 2009 & $3.138,27$ & 1,75 & $1.793 .294,85$ \\
\hline 2010 & $3.491,53$ & 1,69 & $2.065 .995,85$ \\
\hline 2011 & $3.163,69$ & 1,84 & $1.719 .384,78$ \\
\hline 2012 & $2.445,58$ & 2,08 & $1.175 .757,69$ \\
\hline 2013 & $3.731,67$ & 2,35 & $1.587 .766,38$ \\
\hline 2014 & 4.444 .241 & 2,64 & $1.683 .424,62$ \\
\hline 2015 & 7.572 .238 & 3,87 & $1.956 .662,27$ \\
\hline 2016 & $9.734,48$ & 3,35 & $2.905 .815,52$ \\
\hline 2017 & $9.614,93$ & 3,29 & $2.922 .470,21$ \\
\hline 2018 & $9.618,24$ & 3,98 & $2.146 .641,95$ \\
\hline 2 RESULT & $60.493,54$ & & $\mathbf{2 1 . 9 4 5 . 9 2 2 , 6 9}$ \\
\hline
\end{tabular}

Source: prepared by the author (2019).

The results of the AIS from 2007 to 2018 show that the company's stock earnings grew year after year, shortly after the initial public offering on B3. The company's entry 
into the international market and into the world's major stock markets has contributed to the achievement of extraordinary profits. In this sense, one might argue that the company could increase its profits with securities, without making additional investments in research to increase the production of green ethene, the raw material which green PEs and PP are made of. The production of green ethene has always been the same, i.e. 200,000 t/y. A company that presents liquidity of its assets is of high interest for the financial market and for investors. Therefore, it is likely that when Braskem consolidated its position in the national and international financial markets, its management realized there was no need to maintain high investments in new technologies or patents related to the production of green PEs. Instead, they needed to stay in the securities market.

The AISs from 2010, when Braskem started production of green PE, until 2017, show there was growth of revenues. However, although revenues increased in the period, it can be observed that in the period that presents the highest gains in the AIS was from 2007 to 2014. In turn, between 2015 and 2018, the peak of the economic crisis in Brazil, there was a flight of foreign capital, since the Brazilian real was devalued. In addition, Braskem's stock earnings on B3, shown year by year in Table 2, total $\mathrm{R} \$ 60,493,542.00$ from 2007 to 2018. Thus, it can be argued that the reason why there has been a fall in the number of patents over the years is that capital gains are larger and require smaller investments.

In order to calculate how much Braskem profits from the carbon credits obtained from the production of green PEs, one must consider that for every ton of green ethene produced, 85.2 tons of sugarcane are needed, which remove 4,75 tons of $\mathrm{CO}_{2}$ from the atmosphere [11] (BRASKEM, 2020). Braskem produces 200,000 tons of green ethene per year in the Triunfo plant. Considering that the average price of the carbon credit asset on BVRIO was in 2018 US \$ 8.00, and multiplying that number by $950,000(4,75$ x 200,000) tons of $\mathrm{CO}_{2}$ removed from the atmosphere, with the production of the 200,000 tons of green ethene, total for 2018 would be US\$7,600,000. In short, Braskem could have earned approximately US\$ $7,600,000$ in 2018 , related to the trading of carbon credits resulting from the production of 200,000 tons of green ethene obtained from the dehydration of ethanol from sugarcane. Braskem's profits with carbon credits from 2010 to 2017 can be calculated based on the closing price of the trading session for the green asset. It appears, therefore, that the gains from carbon credits in the period were greater than the gains in the AIS. For this reason, it is important to carry out 
studies on the company's balance sheet, not available despite SOX requirements, between 2007 and 2018, to verify what were the actual earnings related to the company's assets (BRKM3, BRKM5 and BRKM6).

It should be highlighted that, considering all of Braskem's polymer production units, the company's overall carbon emissions are higher than the amount of carbon dioxide that the green PEs plant removes from the atmosphere. Its approximate production of 200,000 t/y is much smaller than the production of polymers of fossil origin. Braskem is considered a green company because it is more sustainable than others, which do not produce green polymers.

The prospect of increasing the production of green ethene is small because sugarcane already occupies $0.02 \%$ of the Brazilian ploughed land, as it meets current demand [6-8] (DIAS, 2015; AMANN, 2013; GARCÍA, 2020). However, even if the "I'm green"TM" EVA and PP are produced on an industrial scale, or any other polyaddition polymer that uses ethene as a raw material, the profits from BRKM5 on B3 will be very high. In other words, speculation in the production of Braskem new green polymers at the expense of the same amount of green ethene produced today is a device for capital gains.

\section{FINAL CONSIDERATIONS}

The present work is grounded in the premise that the production of green ethene from the dehydration of sugar cane ethanol is an important ally in the decarbonization of the environment. There are different green polymers that can be obtained from green ethene, and Braskem produced or produces, on a laboratory or industrial scale, HDPE, LLDPE, PP and EVA. When looking at the growth curve of the number of green PEs and PP patents over the period investigated, which was from 2007 to 2018, one notices that the number of patents granted has decreased since 2013. Another interesting point is that the application of these patents in the market is observed mainly in the packaging sector, in films and in bottles. However, by looking at the company's financial data, it was possible to understand that the investments in securities in the Brazilian financial market (BRKM5 and carbon credits) are much more attractive than the investment in new patents, because they generate greater gains $(268 \%$ increase in the average share price of BRKM5 from 2012 to 2018) and do not require large investments in R\&D. In 2018, the gains with carbon credits from the production of green ethene may have been of US\$7,600,000, higher than that obtained from Braskem's AIS. If the company 
maintains positive marketing, such as the one achieved through the "I'm green TM" certification, which is granted to all of Braskem's green products, new investments in the commercial production of other green products, such as PP, EVA or any other polyaddition polymer are not indispensable. In addition, even if the green polymer is blended with the fossil one, the material will be considered green, and it will live up to the label "I'm green TM", provided that the green polymer content is at least $51 \%$.

We have contacted the GVces team in order to try to gain access to relevant information on the Braskem Inventory Reports from 2010 to 2018. However, we were informed that only shareholders may have access to this information, according to the rules currently in force in the financial market, as established by B3 and the Securities and Exchange Commission of Brazil (CVM). However, B3 is agreed to the international financial market rules, such as the Sarbanes-Oxley Act (SOX), which determines transparency of all business activities. Therefore, B3 must submit the reports to the public. Thus, non-compliance with the rule was observed.

During the technical visit to the Braskem-CTI Technology and Innovation Center, it was observed that the ethanol flow from the State of São Paulo to Triunfo does not occur by railroad, but byroad instead, which are not part of the ethanol production cycle. Thus, these emissions from Diesel trucks should be accounted for in the production of green ethene.

Although Braskem is not the company that holds the most patent documents between 1999 and 2017, it is the only company in the world that produces ethene obtained from sugarcane, that is, the only one that generates carbon credits with the production of green ethene. The downward curve in the number of patents for green PEs and $\mathrm{PP}$ raises a question as to whether the great powers and multinational companies are really concerned about the decarbonization of the atmosphere and the positive environmental effects that investments in this direction bring for the planet. If the world's major powers are concerned about the Greenhouse Effect, why are there no mechanisms to force companies to invest in technologies and products that contribute to the decarbonization of the environment? Development, innovation and research related to new processes, environmentally cleaner and sustainable materials exist. Proof of this is the work that the company Braskem has been doing since the beginning of the production of green PEs and PP. The problem is the presence of a highly capitalist model that accumulates wealth and concentrates income, which has prevented advances towards the well-being of the world's population. 
On taking into account the importance of the data obtained in this study, a further procedure aims at its continuation in Brazil. It will include the development of a project about how small and medium companies may have profits through the development of environment friendly projects, specifically Clean Development Mechanisms (CDM) that generate carbon credits. A startup will be created to help these companies to certificate their CDMs and have profits using clean technologies in a transparent way.

Declarations of interest / Conflicts of interest - On behalf of all the authors, it is declared that there are no financial and personal relationships with other people or organizations through the following: employment, consultancies, stock ownership, honoraria, paid expert testimony, patent applications/registrations, and grants or other funding, which would inappropriately influence this study. The first author was a doctorate student and the second, the supervisor of this research.

Acknowledgements - The authors wish to thank the National Council for Scientific and Technological Research (CNPq) for the Fellowship to one of the author (CNPq Process No. 304421/2017-0) and to the company BRASKEM S/A that sent us polymer samples (HDPE and LLDPE green and fossil. The authors would also like to thank Tamara Flores-Sahagun and the Academic Publishing Advisory Center (Centro de Assessoria de Publicação Acadêmica, CAPA - $\underline{\text { www.capa.ufpr.br) }}$ of the Federal University of Paraná (UFPR) for assistance with English language editing.

Author contribution - Eliana Hellvig: doctorate student in the Post-graduation course in Mechanical Engineering (PGMec), Paraná Federal University (UFPR); Thais FloresSahagun: supervisor professor.

\section{REFERENCES}

[1] WATERS, N.; VALVO, N. Synthesis of green polyethilene from sugarcanebased ethanol. Access June 10, 2018. WIPO- World Intellectual Property Organization. USA: Autor. In:< dehttp://www.wipo.int/pct/pt.> Access Jun 10, 2018.

[2] BORSATTO, J. M. L. S; BAZANI, C.; AMUI. L. Regulamentações Ambientais, Inovação Verde e desempenho: Uma análise de empresas dos setor industrial de 
países desenvolvidos e países em desenvolvimento. BBR. In < 601-Article\%20Text-17751-10-20200727\%20(2).pdf> Access July, 2020.

[3] PEREIRA, A. F.A; STOCKER, F; MASCENA, K.M.C; BOAVENTURA. J.M.G. Desempenho social e desempenho financeiro em empresas brasileiras: Análise da influência do Disclousure. BRR- <Article\%20Text-1779-1-10-20200727.pdf> Access July, 2020.

[4] APAK, S., \& ATAY, E. (2015). Global competitiveness in the EU through green innovation technologies and knowledge production. Procedia-Social and Behavioral Sciences, 181, 207-217. https://doi. org/10.1016/j.sbspro.2015.04.882

[5] OKSMAN, K.; MATHEW, A.P.; BISMARCH, A.; ROJAS, O.; SAIN, M. Handbook of green materials - Processing Technologies Properties and Application, v. 5, 1124 pages. DOI - 101142/8975, June 2014.

[6] AMAN, E.; BAER, W.; COES, D.V. Energy bio fuels and Development Comparing Brazil and The United States. Routledge Studies in Development Economics, 334 pages, ISBN 97780415746359, 2013.

[7] DIAS, M.O.S.; FILHO MACIEL, R.; MANTELATTO, P.E.; CAVALETTI, O.; ROSSELL, C.E.V.; BONOMI, A.; LEAL, M.R.L.V. Sugarcane processing for etanol and sugar and Brazil. Environmental Development, v. 15, p. 35-41, 2015.

[8] GARCÍA, C. A; FUENTE, A.; RENNECKE, A; RIEGELHAUPT, E.; MANZINI, F. and MASERA, O. Life-cycle greenhouse gas emissions and energy balance of sugarcane ethanol production in Mexico. In Access 11 June 2020.

[9] COUTINHO, Fernanda et al. Polietileno: Principais Tipos, Propriedades e Aplicações. Revista Ciencia e Tecnologia, v. 13, n 1, p. 1-13, 2003. Disponível em< http://www.scielo.br/pdf/po/v13n1/15064.pdf> Acessado em 09 de jan de 2016.

[10] BASTOS, V. D. Biopolímeros e polímeros de matérias-primas renováveis alternativos aos petroquímicos. Revista do BNDES, 14(28), 201-234, 2007.

[11] BRASKEM: PlásticoVerde. In: Access June 11, 2020. BOLSA DE VALORES DE SÃO PAULO- B3: Índice de Sustentabilidade. São Paulo. In: Access June 9, 2020.

[12] SAJID, M.J. Inter-sectoral carbon ties and final demand in a high climate risk country: The case of Parkistan. JCLE, doi 101016/j.jclepro.2020.122254, v.269, 2020.

[13] QU, C.; SHAO, I.; CHENG, Z. Can embedding in global value chain drive green growth in China's manufacturing industry? JCLP, https://doi.org/10.1016/j.jclepro.2020.121962, 2020.

[14] HELlVIG, F. L. Eliana. Estudo sobre a inovação, patentes concedidas de polipropileno e polietilenos verdes no período de 1999 a 2017 e sua relação com a descarbonização do meio ambiente: o caso BRASKEM. Tese de Doutorado - UFPR, 2019. 
[15] OLIVEIRA, L.B.; RUSSO, S.L.; MARQUES, L.G.A., GOMILA, J.M.V. Technological productivity on control of Boophilus Microplus tick: A patentometric study". Int. Journal of Advanced Engineering Research and Science, v.6(2), p. 134-143, 2019.

[16] ASSAF, Alexandre Neto. Mercado Financeiro. 12a edição. São Paulo. Editora: Atlas, 2012.

[17] BOVESPA- B3: Índice de Sustentabilidade. In< www.b3.com.br/pt_br/marketdata-eindices/indices/indices-de-sustentabilidade/> Access July 13, 2019.

[18] BACEN. Banco Central do Brasil. In: Access October 2, 2019.

[19] MENEGUETTI, N.A. A Reconstrução Produtiva do Setor Sucroalcooleiro no Brasil de 1975 a 1999. Dissertação de mestrado, UEM, 2019.

[20] MOHANTY, A.; MISRA, M.; DRZAL, L. Sustainable bio-composites from renewable resources: opportunities and challenges in the green materials world. Journal of polymers and the Environment, v. 10, n.1-2, p. 19-26, 2002.

[21] DE PAOLI, Marco Aurelio. Degradação e Estabilização de polímeros. $2^{\text {a }}$ edição. São Paulo. Editora: Artliber, 2008.

[22] SCOTT, G. Green polymers. Polymer Degradation and Stability, v. 68, n. 1, 2000.

[23] ALTINBALIK, T.; EKSI, O.; KARABEYOGLU S.: CABBAR, E. Thermoforming of biopolymer-green polyethylene sheets. Int. J. of Modern Manufacturing Technologies, v.10(2), p. 2067-3604, 2018.

[24] XU, J.; XIA, R.; ZHENG, L.; YUAN, T.; SUN, R. Plasticized hemicellulose/chitosanbased edible films reinforced by cellulose nanofiber with enhanced mechanical properties. Carbohydrate Polymers, v. 224, 115164, 2019.

[25] GONZÁleS, G.; GASTElÚ, G. N.; BARRERA, P.D.; RIBOTTA, C.I.A. IGARZABAL. Preparation and characterization of soy protein films reinforced with cellulose nanofibers obtained from soy beans by-product. Food hydrocolloids, v.89, p.758-764, 2019.

[26] MARTELli-TOSA, M.; MASSON, M.M.; SILVA, N. C.; ESPOSTO, B.S.; BARROS, T.T.; ASSIS, O.B.G.; TAPIA-BLÁCIDO, D.L; Soybean straw nanocellulose produced by enzymatic or acid treatment as a reiforcing filles in soy protein isolate films. Carbohydrate Polymers, v. 198, p. 61-68, 2018.

[27] CAO, L.; GE, T.; MENG, F.; XU, S.; LI, J.; WANG, L. An edible oil packaging film with improved barrier properties and heat sealability from cassia gum incorporating carboxylated cellulose nanocrystal whisker. Food hydrocolloids, v. 98, 105251, 2020.

[28] DICKER, M.P.M.; DUCKWORTH, P.F.; BAKER, A.B.; FRANCOIS, G.; HAZZARD, M.K. Green composites: a review of material attributes and complementary aplications. Composites part A, v. 56, p. 280-289, 2014. 
[29] MOSTAFA, H.; YOUSSEF, A.M; DARWISH, N.A; ABOU-KANDIL, A.I. Ecofriendly polymer composites for green packaging: future vision. Composites Part B, v. 172, p. 16-25, 2019.

[30] LIN, Y.S; KUO, P.Y. Tailored optical and mechanical properties of nanocellulose composites: From green natural fibers to strong hybrid reinforcements. Earth Environments Science, v. 268, 012140, 2019.

[31] HEGYESI, N.; ZHANG, Y.; KOHÁRI, A.; POLYAKE, P; SUI, X.; PULÁNSZKY, B. Enzymatic degradation of PLA/cellulose nanocrystal composites. Industrial Crops \& Products, v. 141, 111799, 2019.

[32] SEONE, I.T.; CERRUTI, P.; VASQUEZ, A.; CYRAS, V.P.; MANFREDI, L.B. Ternary nanocomposities based on plasticized poly (3-hydroxybutyrate) and nanocellulose. Polymer Bulletin. In: , 2018.

[33] PLATNIEKS, O.; BARKÃNE, A.; IJUDINA, N.; GAIDUKOVA, G.; THAKUR, V.K.; GAIDUKOVA, S. Sustainable tetra pak recycled cellulose/poly (butylene succinate) based woody-like composites for a circular economy. JCLP, https://doi.org/10.1016/j.jclepro.2020.122321, 2020.

[34] HEINZEN, D. A. D. M.; MATTOS, A. P. M. N.; CAMPOS, L. M. D. S. \& PALADINI, E. P. Estudo de viabilidade de produto inovador "verde" para o mercado consumidor comum. Revista Gestão Organizacional, 4(2), 122-131, 2011.

[35] NEVES, M.F.; TROMBIN, V. G.; CONSOLI, M. A. Measurement Of sugar cane chain in Brazil. International Food and Agribusiness Management Review. v.13. n. 3. p.37-54, 2010.

[36] REIS, G. G. Inovação no Desenvolvimento de Plásticos "Verdes" e com menores Carbon Footprints: $O$ caso do Polietileno de álcool de cana de açúcar da Braskem. ANPAD - Estudos em Estratégia IV Encontro, 2009.

[37] RODRIGUES, R. A.J. Do Engenho à Biorrefinaria. A Usina de açúcar como empreendimento industrial para a geração de produtos bioquímicos $\mathrm{e}$ biocombustíveis. Química Nova, v. 34, n. 7, p. 1242-1254, 2011.

[38a] HELLVIG, E.L; FLORES-SAHAGUN, T.H.S. Desenvolvimento Sustentável para empresas brasileiras: a nova proposta da Economia Hipocarbônica como estratégia de obtenção de lucros através dos créditos de carbono. Revista Brazilian Journal of Development, v. 6 (5), p. 25456-25472, 2020.

[38b] HELLVIG, E.L; FLORES-SAHAGUN, T.H.S.; CARVALHO FILHO, M.A.S.; GONZALES, R.M.; TANOBE, V. O. A; SANTAMARIA, L.C; RAMIREZ, M.G.L. Estudo do uso de eteno verde ou fóssil na síntese de PEAD e PELBD nominalmente iguais: há diferença efetiva entre esses materiais? Revista Brazilian Journal of Development v. 6 (5), p. 25473-25487, 2020.

[39] RAMIRES, E. C.; MEGIATTO, J. D. JR.; GARDRAT, C.; CASTELlAN, A.; FROLLINI, E. Biobased composites from glyoxal-phenolic resins and sisal fibers. Bioresour Technol, v.101, n.6, p.1998-2006, 2010. 
[40] NARAJAN, R. Drivers \& Rationale for Use of Biobased Materials Based on Life Cycle Assessment (LCA). Global Plastics Environmental Conference, Detroit, February 18-19, 2004.

[41] GIANNETTI, B. F. \& de ALMEIDA, C. M. V. B. Ecologia industrial:conceitos, ferramentas e aplicações. Editora: Edgard Blücher. São Paulo, 2006.

[42] GEYER, Roland; BLASS Vered Doctori. The economics of cell phone reuse and recycling.Int J. Adv. Manuf. Technol. V. 47, p. 515 - 525, 2010.

[43] FAlCONE, B. M. D. Panorama Setorial e Perspectivas na Área de Polímeros Biodegradáveis. Polímeros: Ciência e Tecnologia, v.17, n. 1, p. 5-9, 2007.

[44] LANCELlOTTI, A. Bioplastics in Brazil: Beyond the Green Speech. Frost \& Sullivan. São Paulo: Autor. In:< www.frost.com> 2010.

[45] JESUS, S.M.S.; OLIVEIRA Jr, A.M. Patentometric analysis of the transfer of technology in Brazil between 2010 and 2018. Int. J. of Innovation Education and Research, v.7(7), 112-123, 2019. 